Vol.10, Issue 1, pp. 17-34, 2022

Online ISSN: 2054-636X (Online)

Print ISSN: 2054-6351(Print)

\title{
ASSESSMENT OF SUPERVISION IN PUBLIC BASIC SCHOOLS IN NORTHERN GHANA: THE CASE OF LAMBUSSIE-KARNI DISTRICT
}

\author{
${ }^{1}$ Enock Yeng, ${ }^{2}$ Anthony Woode-Eshun \& ${ }^{3}$ Seth Badu \\ 1, 2, 3University of Education, Winneba
}

\begin{abstract}
This study sought to assess the effectiveness of supervision in public basic schools in Lambussie-Karni District of the Upper West Region of Ghana. The descriptive survey design was adopted, where quantitative data was collected and analyzed. The multi-stage sampling with the use of stratified random sampling and convenience sampling techniques were used to select 234 participants for the study. Structured questionnaire was used as instrument for data collection. Version 25 of the Statistical Product for Service Solution was used to analyze the data. The mean and standard deviation were used to analyze the data. The study revealed that clinical supervision was dominantly practiced than training and guidance supervision, collegial supervision and traditional supervision. Also, participants perceived all the components and well as the overall supervision as very effective in promoting effective teaching and learning. The challenges to effective supervision included unhealthy relationship between supervisors and supervisees, lack of regular inservice training, lack of funds, and follow-up activities. It was recommended that regular in-service training should be organized by Ghana Education Service (GES) for supervisors and teachers to update their knowledge and skills, and to be abreast with the changing trends in supervision in schools.
\end{abstract}

KEYWORDS: supervision, assessment, headteachers, teachers.

\section{INTRODUCTION}

The $21^{\text {st }}$ century has witnessed an increasing consensus among researchers and practitioners in the field of education since education is seen as a vehicle for socioeconomic advancement of a society. In line with this assertion, Dangara (2015) claims that education remains the biggest instrument for academic progress, social mobilization, political survival and effective national development of any country. Arguably, it could be said that education is the light that has the capacity of helping any individual to be able to navigate through the complex society.

Accordingly, with the adoption of the Sustainable Development Goal (SDG) on Quality Education (Goal 3), governments worldwide have prioritized quality primary education in policy agendas. The Government of Ghana has been committed to the achievement of Universal Basic Education by ensuring that all children of schoolgoing age would have completed a full course of primary schooling. Therefore, various government of Ghana have been implementing various interventions such as the capitation grant, school feeding programme, free exercise books and uniforms to improve access to education. In line with the above commitment by successive 
government to the realization of this goal, the New Patriotic Party (NPP) in the year 2017, with a broader consultation introduced the Free Senior High School Policy (FSHS) which has since seen over 1.2 million students benefiting from this policy from 2017 to date (GES, 2021). These interventions are also in pursuit of granting the right to education to all as stipulated in International Law and Ghana's Constitution, and Human Right Standards (Kadingi, 2004). The Education Sector Performance Report (2013) clearly affirms the implementation of the aforementioned interventions which have resulted in increased enrolment.

Besides, issues of quality education are prominent in all countries, particularly those that are presently expanding enrolments to achieve the goal rapidly toward Education for All. Many of these countries are simultaneously introducing complex reforms in teaching and learning which are related to more active forms of learning. However, rapid expansion, changing paradigms of teaching and learning, and limited resources have led to declining quality of education in many countries (USAID, 2006).

In recent times there has been a serious public outcry about the fallen standards of education especially on student academic performance during external examinations, and several factors has been attributed to this state of affair (Aluja-Fabregat \& Blanch, 2004; Bashir \& Mattoo, 2012). According to Dampson and Mensah (2010) persistent parental courage and determination to persevere and defy all obstacles affect students' attitudes toward education, and influence performance. Similarly, Kundu and Tutoo (2000) believe that home background is the most significant primary factor which influences and shapes children's attitudes, personality and behavior patterns that lead to good performance at schools.

There is plethora of theoretical and empirical proofs to sustain the argument that supervision matters in ensuring quality education. Etsey, Amedahe and Edjah (2004) validate this argument when their study of some private and public schools in Ghana revealed that academic performance is better in private schools due to more effective supervision of work. Thus, effective supervision improves the quality of teaching and learning in the classroom which lead to good academic performance. Sule (2013) also endorses this by indicating that school supervision (internal or external) has become an essential instrument for checking teachers' job performance.

Studies have documented that supervision occupies a unique place in the entire education system and it becomes absolutely expedient to give it prominent attention (Baffour-Awuah, 2011, Ayse Bas, 2002, Daresh, 2001). In contemporary times, instructional supervision is regarded as the process of enhancing the professional growth of the teachers, the curriculum and improving the techniques of teaching in the classroom through democratic interactions between the teacher and the supervisor (Okendu, 2012). The National Open University of Nigeria (NOUN) (2006) observed that supervision provides opportunities for teachers to be groomed through critical study of instructional processes and classroom interactions to carry out their teaching tasks in line with professional codes of conduct. Dangara (2015) also argues that if schools are not supervised adequately, it will have inimical effects on the students' output, and the educational objectives may not be achieved. Consequently, various 
instructional supervisory techniques should be employed to ensure qualitative and quantitative service delivery by the teachers.

In the Ghanaian context, the issue of supervision has become a serious concern for educational stakeholders and has been subjected to serious scrutiny. In the light of the above, Mensah (1995) argues that the success of a school depends largely on the head of the school, how he or she perceives supervision, and how he/she performs his or her roles. It is therefore important to state that school heads need to plan instructional programmes that will bring about excellent performance and effective supervision of schools (Danso, 2009).

The Ghana Education Service (GES) has a structured system to ensure effective supervision at the pre-tertiary level. There is an Inspection Division at the GES headquarters which oversees and coordinates supervisory activities under its jurisdiction. At each Regional Directorate, there is a supervision unit headed by the Chief Supervisor of schools, and at the Metropolitan/Municipal/District Directorates, supervision is the responsibility of the supervision unit headed by the Deputy Director of Education with a team of circuit supervisors. Finally, at the school level, supervision is spearheaded by the head teacher.

Empirical studies have outlined the necessity to improve instructional supervision in the classroom to improve student performance (Sergiovanni \& Starratt, 2002; Sullivan \& Glanz, 1999). Nakpodia (2006) asserts that, instructional supervision in the modern era centers on the improvement of the teaching-learning situation to the benefits of both the teachers and learners. This helps in the identification of areas of strength and weaknesses of teachers, follow-up activities that should be directed at the improvement of identified areas of teachers' weaknesses, give recognition to the teachers, and create a cordial working atmosphere based on good human relations.

Among the challenges of instructional supervision in Ghana lies in the fact that some teachers see supervision as a tool used by head teachers and circuit supervisors to control and intimidate them. This notion makes teachers feel unsafe and threatened when they experience any form of supervision (Baffour-Awuah, 2011). Ayse Bas (2002) found that some teachers feel supervision is an intrusion into their private instructional practices. Nevertheless, practitioners like Acheson and Gall (1997) observe that teachers are not impervious to supervision but rather to the supervision styles and attitudes adopted by supervisors in discharging their duties. Ayse Bas (2002) substantiates this claim when he observed that teachers bemoaned that the supervisors' intrusive monitoring, physical presence, and their coercive nature changed the setting in the classrooms which resulted in false impressions. It is argued that supervision of instruction as an effective mechanism in schools could facilitate the achievements of educational goals (Okwundu, 2012). The issue is "which supervisory style is suitable to enhance effectiveness of supervision?" From the above exposition, supervision of instruction assumes a cardinal field of study. 


\section{Statement of the Problem}

The issue of quality education has been discussed in many forums globally. According to the World Bank (2002) quality of education is poor especially at all levels in low-and-middle-income countries. Students in developing countries have a mean level of achievement below that in industrial countries, and their performance shows a much greater variance around the mean as lack of quality remains a major problem in many educational systems. Meanwhile, scholars and practitioners in the field of education have underscored that one of the ways of ensuring quality education is supervision. Okwundu (2012) observes that supervision in schools is carried out with a view of ensuring quality and effectiveness of teaching and learning activities (classroom instruction). Okwundu further argues that for quality to be assured in primary schools there is need for effective supervision of instruction geared towards achieving educational objectives. Consistent with this, Oyewole and Ehinola (2014) remark that supervision of instruction is important for the realization of an effective education system.

Empirical studies have continually established that supervision of instruction has the potential to improve classroom practices, and contribute to student success through professional growth and improvement of teachers (Sergiovanni \& Starratt, 2002, Blasé \& Blasé, 1999; Sullivan \& Glanz, 1999; Musaazi, 1985). The educational sector in general is hampered by persistent deficiencies which stems from input, access, output and outcome indicators which show that appropriate information systems require to cover the whole process from supplying educational services demand factors and accessibility to results in terms of educational performance and externalities derived from enhanced human capital formation (Screens, et al., 2011). In the Lambussie-Karni District, it is observed that quality indicators in terms of inputs such as chalk, teachers' notebooks, and financial support (capitation grant) are inadequate. This could account for the seeming drop in the academic performance of public basic school pupils in the District, hence, the issue of supervision has come under scrutiny by stakeholders of education.

Poor supervision has been identified as the main cause of poor academic performance of pupils in external examinations. For instance, Etsey, Amedahe and Edjah (2004) studied some private and public schools in Shama District and the findings were that academic performance is better in private schools as a result of effective supervision of work. Similarly, Oduro (2008) established that poor performance of pupils especially in public schools is the outcome of ineffective supervision of teachers. However, there seems to be no study on the nature of supervision, its effectiveness, and challenges in the Lambussie-Karni District in the Upper West Region of Ghana. As a result of this, it is imperative to conduct this study to contribute to knowledge and literature on supervision of instruction in schools.

\section{Purpose of the Study}

The purpose of this study was to assess the effectiveness of supervision in public basic schools in the Lambussie-Karni in the Upper West Region of Ghana. 
Vol.10, Issue 1, pp. 17-34, 2022

Online ISSN: 2054-636X (Online)

Print ISSN: 2054-6351(Print)

\section{Research Questions}

The following research questions directed the study:

1. What supervisory style is mostly practiced in public basic schools in the Lambussie-Karni District?

2. How effective is the supervision carried out in public basic schools in the Lambussie-Karni District?

3. What challenges confront effective supervision in public basic schools in the Lambussie-Karni District?

4. What needs to be done to enhance effective supervision in public basic schools in the Lambussie-Karni District?

\section{Significance of the Study}

This study will have implications for policy, practice and research. It is hoped that the findings of the study will inform policy-makers like the Ministry of Education and Ghana Education Service on the state of supervision in the district. It is hoped that the findings of the study would be beneficial to head teachers, teachers, pupils, and education officers at the District Directorate. It is envisaged that the findings of the study would help head teachers and circuit supervisors to be aware of their supervisory styles, and identify the supervisory styles that will enhance effective supervision in basic schools in the District. Also, the findings may be beneficial to the Ghana Education Service (GES) since it may serve as a framework for planning, reorganizing and providing training and development programmes for present and future educational supervisors through seminars, workshops, and short courses. Finally, it could also serve as a reference material for future research.

\section{Research Design}

This study employed descriptive survey design. The descriptive survey design makes possible for the prediction of the future on the basis of findings on prevailing conditions. Descriptive survey helps to gather data at a particular point in time with the intention of describing the nature of existing condition or identifying standards against which existing conditions can be compared or determining the relationship that exist between specific events. (Cohen, Manion \& Morrison, 2011).

The population of the study comprised all the circuit supervisors, head teachers and teachers in public basic schools in the Lambussie-Karni District. The target population was all circuit supervisors, head teachers and teachers who had worked in their schools for at least one year.

A sample size 263 was selected and used for the quantitative aspect of the study. This number was consistent with the argument put forward by quantitative researchers which lies in the fact that it is able to produce a stronger data and results. A sample size of 12 participants was used for the qualitative face of the analysis. This number is in line with recommendations by Whitehead and Annells (2007) that eight to fifteen participants is appropriate for qualitative studies.

The Multistage sampling technique was used for the study. The stages included the use of purposive, stratified random and convenience sampling techniques. At the first 
stage, all circuit supervisors and head teachers were purposively selected. Purposive sampling is a non-random sampling technique where the researcher selects the sample arbitrarily which is considered important for the research and believes it has typical and representative of the population (Nworgu, 2006). Therefore, the views of these persons were critical to understand the issues under investigation.

At the second stage, the stratified sampling was used to select teachers. In this sampling technique, categorization was done according to sex after which a random sampling was done. Fink (1995) observes that stratified random sampling is one in which the population is divided into subgroups or 'strata,' and a random sample is then used to select from each subgroup. The rationale for using this sampling strategy was to ensure that units in each category of the population of interest were represented in the sample. Particularly, proportionate stratified random sampling where the same fraction as in the population for each subgroup was used. The stratified random sampling method was used because of its prospects of accuracy, easy accessibility as well as better comparison and representation across strata (Saunders, Lewis \& Thornhill, 2007).

Convenience sampling includes participants who are readily available and agree to participate in a study (Fraenkel \& Wallen, 2000). Therefore, participants who were available at the time of data collection and agreed to participate in the study were selected. With this in mind, 12 respondents which included circuit supervisors, head teachers and teachers were interviewed. These were respondents who agreed to participate in the interview.

The instrument adopted for data collection was structured questionnaire. It was used to collect data because it is appropriate in obtaining and given a vivid description of the data.

The researcher personally administered the questionnaire to the respondents who filled and return them immediately. Out of the two hundred and sixty-three (263) questionnaires administered, two hundred and thirty-four were returned, representing a response rate of about - eighty eight percent (88\%). This high response rate was due to the fact that the questionnaires were filled-in and collected immediately. The researcher was present to clarify issues raised by the respondents thereby reduced errors in answering. This response rate was considered appropriate because scholars like Babie (1998) argue that at least 50\% response rate is appropriate in descriptive surveys.

The questionnaire was pre-tested in all four public basic schools in the Sissala West District. The resultant coefficients were 8.22 for headteachers' questionnaire and 8.46 for teachers' questionnaire. These coefficients implied the items in the questionnaire were reliable since a good reliability is indicated by a coefficient greater than 0.8 (Jones and Rattray, 2010). The analysis of the empirical data aims to make sense of massive amounts of data, reduce the volume of information, identify significant patterns, and construct a framework for communicating the essence of what the data reveal (Patton, 1990). Analysis of the data was done quantitatively. The questionnaire 
was coded, and entered via Version 25 of Statistical Product for Service Solution (SPSS). The data were then explored to identify missing data and outliers.

Descriptive statistics such frequency and simple percentages were used to analyze the demographic information and to provide an overview of the variables. The mean and standard deviation were used to answer research questions.

The ethical precautions that were employed included a clear explanation of the research objectives and the process of data collection. The objective of the study was explained to the respondents. Again, confidentiality and anonymity were assured and participants were told of their right to withdraw at any stage of the research process. The researcher respected the rights, needs, values, and desires of the research participants. In order to elicit their consent, the purpose of the study was explained to the respondent before the administration of the questionnaire.

\section{Results and Discussion}

\section{Table 1: Demographic Distribution of Respondents}

\begin{tabular}{|c|c|c|c|}
\hline Variables & & Frequency & Percent \\
\hline \multirow[t]{3}{*}{ Sex } & Male & 160 & 68.4 \\
\hline & Female & 74 & 31.6 \\
\hline & Total & 234 & 100.0 \\
\hline \multirow[t]{5}{*}{ Age } & 20-30 Years & 58 & 24.8 \\
\hline & 31-40 Years & 89 & 38.0 \\
\hline & 41-50 Years & 52 & 22.2 \\
\hline & Above 51 Years & 35 & 15.0 \\
\hline & Total & 234 & 100.0 \\
\hline \multirow[t]{5}{*}{ Highest Academic Qualification } & Post Sec. Cert A & 26 & 11.1 \\
\hline & Diploma & 102 & 43.6 \\
\hline & Degree & 99 & 42.3 \\
\hline & Masters & 6 & 2.6 \\
\hline & Total & 234 & 100.0 \\
\hline \multirow[t]{5}{*}{ Marital Status } & Single & 63 & 26.9 \\
\hline & Married & 162 & 69.2 \\
\hline & Divorced & 6 & 2.6 \\
\hline & Widow & 3 & 1.3 \\
\hline & Total & 234 & 100.0 \\
\hline \multirow[t]{7}{*}{ Rank } & Senior Sup II & 78 & 33.3 \\
\hline & Senior Sup I & 39 & 16.7 \\
\hline & Principal Superintendent & 106 & 45.3 \\
\hline & Assist. Director II & 2 & 0.9 \\
\hline & Assist. Director I & 8 & 3.4 \\
\hline & Deputy Director & 1 & 0.4 \\
\hline & Total & 234 & 100.0 \\
\hline \multirow[t]{6}{*}{ Years of Experience } & 1- 5 Years & 53 & 22.6 \\
\hline & 6-10 Years & 87 & 37.2 \\
\hline & 11-15 Years & 45 & 19.2 \\
\hline & 16-20 Years & 14 & 6.0 \\
\hline & 21 Years and Above & 35 & 15.0 \\
\hline & Total & 234 & 100.0 \\
\hline
\end{tabular}

Source: Field Data, (2021) 
Vol.10, Issue 1, pp. 17-34, 2022

Online ISSN: 2054-636X (Online)

Print ISSN: 2054-6351(Print)

Data in Table 1 revealed that $160(68.4 \%)$ were males and 74 (31.6\%) were females. The sex composition of the sample is important so that information collected would not be gender bias. The age distribution of the teachers showed that $58(24.8 \%$,) of the respondents were between 20 to 30 years, 89 (38.0\%) were between 31 to 40 years. Also, $52(22.2 \%)$ of the respondents were between 41 to 50 years whiles 35 $(15.0 \%)$ teachers were above 51 years.

For academic qualifications of the participants, the analysis revealed that $26(11.1 \%)$ respondents had Post Sec. Cert. 'A', 102 (43.6\%) respondents had Diploma certificates and $99(42.3 \%)$ had Bachelor's Degree, whiles $6(6.5 \%)$ of the respondents were Master's Degree holders at the time of the study. The marital status of the teachers revealed that $63(26.9 \%)$ respondents were single, $162(69.2 \%)$ respondents were married. Again, 6 (2.6\%) respondents were divorced with $3(1.3 \%)$ respondents were widowed at the time of the study.

Table 1 also disclosed that $78(33.3 \%)$ respondents were at Senior Superintendents II with respect to their rank, $39(16.7 \%)$ respondents were Senior Superintendents I. Also, $106(45.3 \%)$ respondents had their rank being Principal Superintendent and 2 (0.9\%) respondents were at Assistant Director II whiles 8 (3.0\%) respondents were Assistant Director I. The results again disclosed that $1(0.4 \%)$ teacher was Deputy Director. The rank distribution of teachers implies that information collected would reflect rich views from different ranks and experience. The information disclosed that $53(22.6 \%)$ teachers had between 1 to 5 years teaching experience, $87(37.2 \%)$ of the respondents had between 6 to 10 years' experience. Again, 45 (19.2\%) respondents had 11 to 15 years' experience and $14(6.0 \%)$ respondents had over 16 years teaching experience and $35(15.0 \%)$ of the respondents had over 21 years' experience at the time of the study.

\section{Analyses of Research Questions}

Research Question 1: What supervisory style is mostly practiced in the LambussieKarni District?

The first research question examined the perception of the participants on the nature of supervision mostly practiced in public basic schools in the district and the results are presented in Figure 1. 


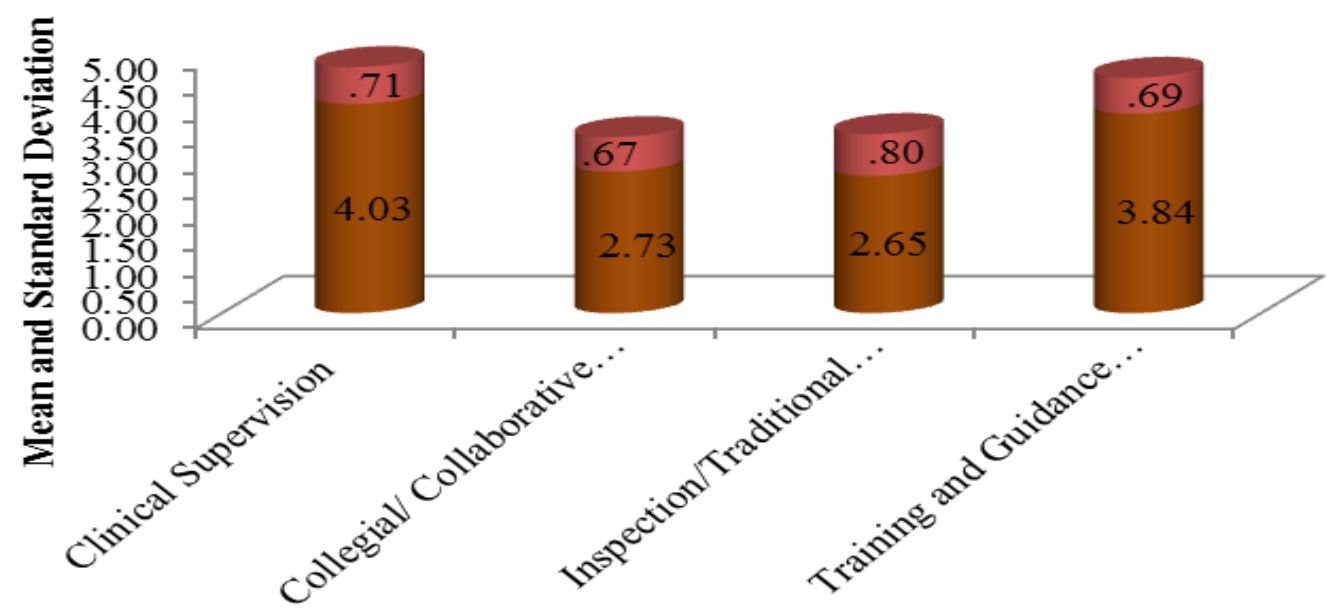

Figure 4. 1 Nature of School Supervision

Source: Fieldwork, 2021

The results in Figure 1 revealed that clinical supervision was dominantly practiced $(\mathrm{M}=4.03, \mathrm{SD}=0.71)$ than training and guidance supervision $(\mathrm{M}=3.84, \mathrm{SD}=0.69)$, collegial supervision $(\mathrm{M}=2.73, \mathrm{SD}=0.67)$ and traditional supervision, $(\mathrm{M}=2.65$, $\mathrm{SD}=0.80$ ). Based on the 5-point Likert scale used for the data where the mean is 2.50 , it could be noticed that all the score for the components of supervision were above the mean and this implies that all the facets of school supervision were common in the schools.

\section{Research Question 2: How effective is the supervision carried out in public basic schools in the Lambussie-Karni District?}

Research Question 2 sought to investigate the perception of participants on the effectiveness of supervision in promoting effective teaching and learning in public basic schools in Lambussie-Karni District. The effectiveness was in relation to effective use of instructional hours, regular in-service training workshops for participants, and punctuality of head teachers and teachers to school. In this study, mean and standard deviation were calculated to determine the perceived effectiveness of the supervision such that when mean $<2.50$, it indicated ineffective supervision, $2.50 \leq$ mean $\leq 3.50$ showed effective supervision, and mean $\geq 3.50$ indicated very effective supervision. The general perception of participants on the effectiveness of the component's supervision is presented in Figure 2. 


$$
\text { Mean } \quad \text { Std. Deviation }
$$

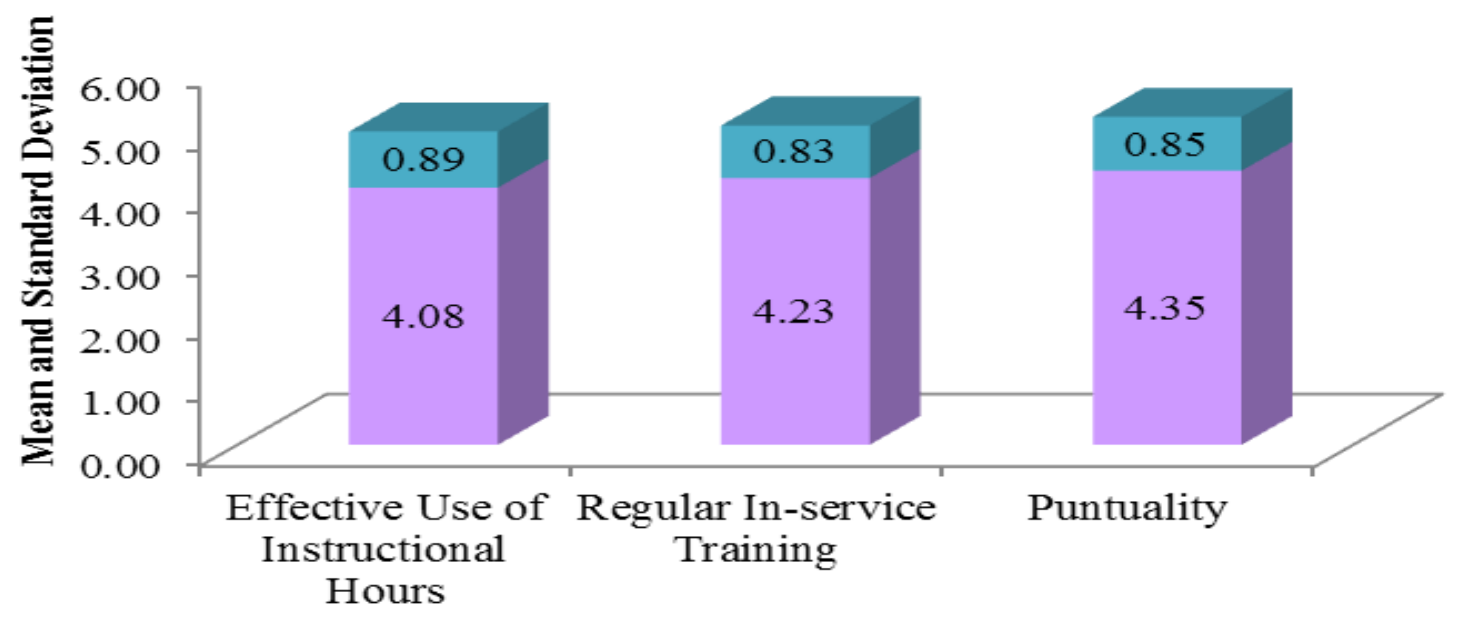

\section{Figure 4. 2 Overview of Participants on Perception of Effectiveness of Supervision}

Source: Field Data (2021)

A look at Figure 2 has revealed that participants conceived the effective use of instructional hours as very effective. This is seen in the mean and standard deviation score $(\mathrm{M}=4.08, \mathrm{SD}=0.89)$. Also, regular in-service training was conceived to be very effective as shown in the mean and standard deviation score $(\mathrm{M}=4.08, \mathrm{SD}=0.83)$. Again, punctuality of supervisors, head teacher and teacher in discharging their duties in promoting quality education was seen as very effective as shown in the mean and standard deviation score $(\mathrm{M}=4.35, \mathrm{SD}=0.85)$. The results indicated that participants perceived all the components as very effective in promoting effective supervision

\section{Research Question 3 - What challenges confront effective supervision in public basic schools in the Lambussie-Karni District?}

The third research question investigated the factors that militate against the implementation of effective supervision in the study area. An overview of these factors is shown in Figure 4.3. 


\section{Mean $\quad$ Std. Deviation}

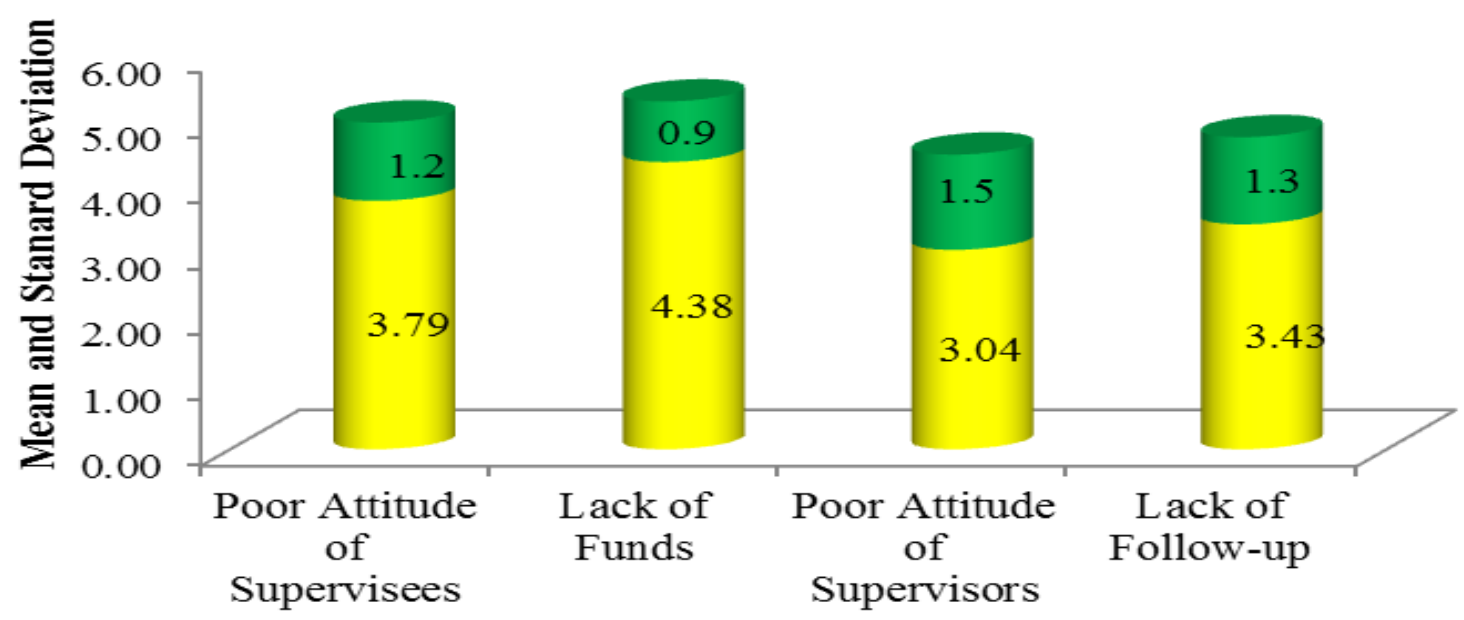

Figure 3: Factors Confronting Implementation of Effective Supervision Source: Field Data (2021)

Figure 3 revealed that lack of funds is perceived to be a challenge in the implementation of effective supervision $(\mathrm{M}=4.38, \mathrm{SD}=0.9)$ than poor attitude of supervisees $(\mathrm{M}=3.79, \mathrm{SD}=1.2)$, lack of follow-up activities $(\mathrm{M}=3.43, \mathrm{SD}=1.3)$, and poor attitude of supervisors $(\mathrm{M}=3.04, \mathrm{SD}=1.5)$.

Research Question 4 - What needs to be done to enhance effective supervision in public basic schools in the Lambussie-Karni District?

This research question sought to solicit the views of participants on measures that could be put in place to improve the standard of school supervision offered at public basic schools in the Lambussie-Karni District of the Upper West Region of Ghana. An overview of these measures is shown in Figure 4.

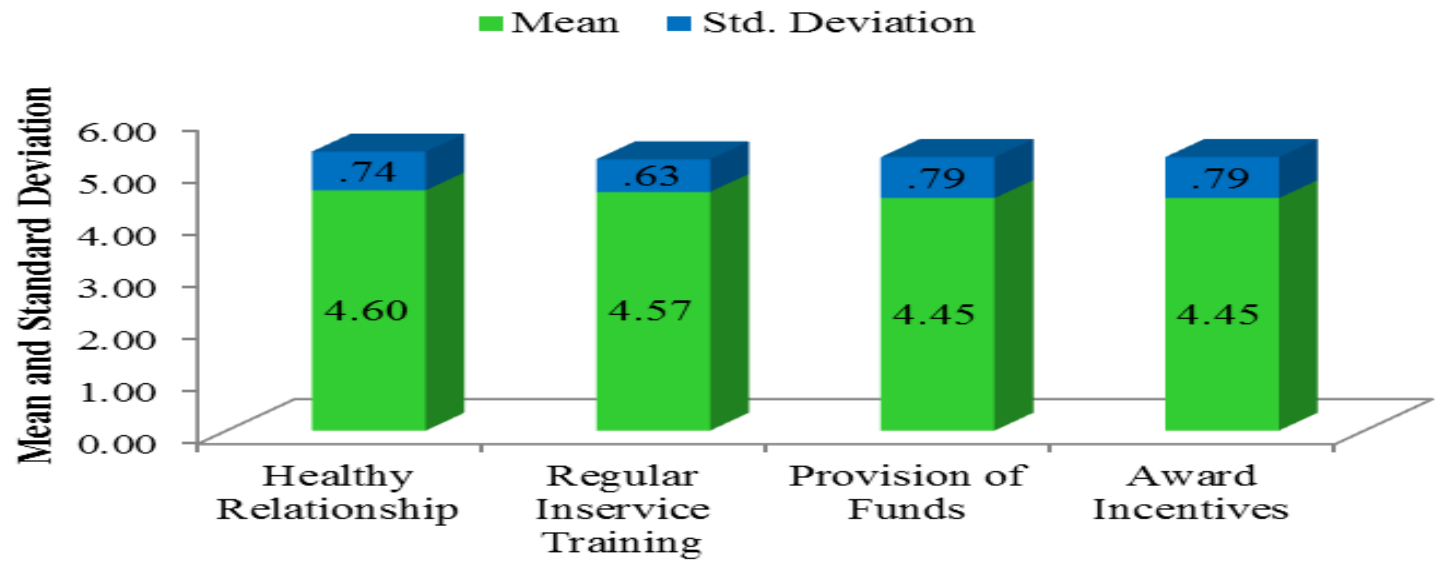

Figure 4 Respondents' Views on Measures of Improving Effective Supervision Source: Field Data, 2021 
Vol.10, Issue 1, pp. 17-34, 2022

Online ISSN: 2054-636X (Online)

Print ISSN: 2054-6351(Print)

The results in Figure 4 revealed that the need for the establishment of healthy relationship between both supervisors and supervisees was more supported ( $M=4.60$, $\mathrm{SD}=0.74)$ than the call for regular in-service training $(\mathrm{M}=4.57, \mathrm{SD}=0.63)$, provision of funds $(\mathrm{M}=4.45, \mathrm{SD}=0.79)$, and giving awards and incentives $(\mathrm{M}=4.40, \mathrm{SD}=0.75)$. Based on the 5-point Likert scale used for the data where the mean is 2.5, it could be noticed that all the scores for the components of measures to improve supervision were above the mean. This implies that participants had a similar view on how supervision could be improved in public basic schools in the District.

\section{Test of the Study's Hypotheses}

$\mathrm{H}_{01}$ : There is no statistically significant difference between male and female participants in their perception of supervisory styles used in public basic schools in Lambussie-Karni District.

An independent samples t-test was used to test the hypothesis and the results are presented in Table 3 .

Table 2: Mean, Standard Deviation and T-test Results for Sex and Supervisory Styles

\begin{tabular}{llccccc}
\hline Variables & Sex & Mean & Std. Dev. & $\mathrm{t}$ & $\mathrm{df}$ & P-value \\
\hline Clinical Supervision & Male & 3.99 & 0.74 & -1.358 & 232 & 0.176 \\
& Female & 4.12 & 0.63 & & & \\
Collegial/Collaborative & Male & 2.68 & 0.64 & -1.713 & 232 & 0.88 \\
Supervision & Female & 2.83 & 0.70 & & & \\
Inspection/Traditional & Male & 2.68 & 0.81 & .830 & 232 & 0.408 \\
Supervision & Female & 2.58 & 0.80 & & 232 & 0.798 \\
Training and Guidance & Male & 3.84 & 0.66 & -.256 & & \\
Supervision & Female & 3.86 & 0.76 & & & \\
& & & & & &
\end{tabular}

Source: Field Data, (2021)

The independent samples t-test results in Table 2 revealed that there was no statistically significant difference in the perception of male $(\mathrm{M}=3.99, \mathrm{SD}=0.74)$ and female participants $(\mathrm{M}=4.12, \mathrm{SD}=0.63)[\mathrm{t}(232)=-1.358, \mathrm{p}=0.176]$ at 0.05 on clinical supervision. Also, there was no statistically significant differences between the views of male $(\mathrm{M}=2.68, \mathrm{SD}=0.64)$ and female participants $(\mathrm{M}=2.83, \mathrm{SD}=0.70)$ [t $(232)=-$ 1.713, p=0.88] t 0.05 for Collegial/Collaborative supervision. Again, there was no statistically significant difference between male $(\mathrm{M}=4.04, \mathrm{SD}=0.38)$ and female participants $(\mathrm{M}=4.08, \quad \mathrm{SD}=0.37) \quad[\mathrm{t}(232)=.830, \mathrm{p}=0.408]$ at 0.05 for inspection/traditional supervision and finally, there was no statistically significant difference between male $(\mathrm{M}=3.84, \mathrm{SD}=0.66)$ and female participants $(\mathrm{M}=3.86$, $\mathrm{SD}=0.76)[\mathrm{t}(232)=.0 .256, \mathrm{p}=0.798,2$-tailed] for training and guidance. These results imply that sex is not a factor that affects participants' perception on the supervisory styles practiced in Lambussie-Karni District. Based on these results, the null 
Vol.10, Issue 1, pp. 17-34, 2022

Online ISSN: 2054-636X (Online)

Print ISSN: 2054-6351(Print)

hypothesis that there is no statistically significant difference between male and female participants in their perception of the supervisory styles practiced in the LambussieKarni District is accepted.

\section{DISCUSSION OF THE RESULTS}

Research Question 1 sought to investigate the nature of school supervision in public basic schools. The results discovered that clinical supervision was dominantly practiced $(\mathrm{M}=4.03, \mathrm{SD}=0.71)$ than training and guidance supervision $(\mathrm{M}=3.84$, $\mathrm{SD}=0.69)$, collegial supervision $(\mathrm{M}=2.73, \mathrm{SD}=0.67)$, and traditional supervision, $(\mathrm{M}=2.65, \mathrm{SD}=0.80)$. However, it was established that all the components of school supervision were common in the schools. This finding is consistent with that of Oja \& Reiman (1998) and Augustyn (2001) who discovered that most beginning teachers require the intensive assistance of clinical supervision to improve their instructional performance, and that the supervisor should also work with them in two other styles namely, a direct supervisory style and flexible collaborative style. It is not surprising that the participants perceived clinical supervision as the most dominant style because their supervisors assisted them in their development.

Research Question 2 examined the perception of participant in terms of the effectiveness of supervision in relation to effective use of instructional hours, regular in-service training workshops for participants, and punctuality of head teachers and teachers to school. It was revealed that participants conceived the punctuality of supervisors, head teachers and teachers in discharging their duties to promote quality education $(\mathrm{M}=4.35, \mathrm{SD}=0.85)$ more than regular in-service training $(\mathrm{M}=4.23$, $\mathrm{SD}=0.83)$ and effective use of instructional hours $(\mathrm{M}=4.08, \mathrm{SD}=0.89)$. The results indicated that participants perceived all the components of supervision as very effective. This finding is congruent with the observation of Esia-Donkoh \& OfosuDwamena (2014) that effective supervision in the basic schools is likely to improve teachers' professional performance and consequently enhance the general output of pupils in the schools.

Research Question 3 examined the perception of the participants on the factors that militate against successful implementation of school supervision in the study area. The results (both quantitative and qualitative) revealed that lack of funds is perceived to be a challenge to the implementation of effective supervision $(\mathrm{M}=4.38, \mathrm{SD}=0.9)$ than poor attitude of supervisees $(\mathrm{M}=3.79, \mathrm{SD}=1.2)$, lack of follow-up activities $(\mathrm{M}=3.43, \mathrm{SD}=1.3)$, and poor attitude of supervisors $(\mathrm{M}=3.04, \mathrm{SD}=1.5)$. This finding is consistent with the findings of Enaigbe (2009) and Mankoe (2002) argues that the most important problem of supervision is lack of mobility. They argued that there can be no effective supervision of instruction without adequate instructional materials. The problem of non-payment of transportation allowance of supervisors, also poses a serious challenge in successfully implementing supervision to achieve the desired results. 
Research Question 4 sought to explore the possible ways by which supervision could be improved in public basic schools in the Lambussie-Karni District. The findings disclosed that there is the need for the establishment of healthy relationship between both supervisors and supervisees $(\mathrm{M}=4.60, \mathrm{SD}=0.74)$ organization of regular inservice training $(M=4.57, S D=0.63)$, provision of adequate funds $(M=4.45, S D=0.79)$, and giving awards and incentives to supervisors $(\mathrm{M}=4.40, \mathrm{SD}=0.75)$. These suggestions in the view of the respondents could go a long way to improve supervision in public basic schools in the Lambussie-Karni District in the Upper West Region of Ghana. This finding agrees with previous studies by (Lilian 2007), Merga (2007) and Rashid (2001).

\section{SUMMARY, CONCLUSIONS AND RECOMMENDATIONS}

\section{Summary}

The study investigated the nature and effectiveness of supervision and also explored the challenges and the ways by which effective supervision could be improved in the public basic schools in the Lambussie-Karni District. The study employed the descriptive survey design for the data collection. Multi-stage sampling was used to collect data from 221 respondents (teachers) and 12 respondents (headteachers). Structured questionnaire as instrument was used to collect data. Descriptive and inferential statistical tools were used for the analysis of quantitative data. Independent samples t-test were used to investigate the influence of sex participants' perception of the style of supervision used in the public basic schools in the Lambussie-Karni District.

The study found that clinical supervision was dominantly practiced than training and guidance, collegial/collaborative, and traditional/inspection in the public basic schools in the Lambussie-Karni District.

It was found out that generally, all the components of supervision were very effective. Specifically, it was discovered that the use of instructional hours, punctuality and regular in-service training were very effective in the supervision processes

Another finding was that factors such as lack of funds, uncooperative attitudes exhibited by both supervisors and supervisees and lack of follow ups by supervisors were some of the challenges that militate against the implementation of effective supervision. It was revealed that lack of funds and the uncooperative attitudes were the major challenges facing implementation of successful supervision in the Lambussie-Karni District.

The study also established that maintaining healthy relationship between supervisors and supervisees, provision of adequate funds, and regular in-service training programs were among the suggested ways by which effective supervision could be improved to bring about quality of teaching and learning in public basic schools in the LambussieKarni District of the Upper West Region of Ghana. Besides, it was revealed that sex did not influence participants' perceptions on the nature of supervision. 


\section{Conclusions}

The findings and the results of the study have produced enough evidence to conclude that effective supervision is carried out in public basic school in Lambussie-Karni District. However, even though clinical supervision was dominant than training and guidance, collegial/collaborative, and traditional supervision, it could be concluded that all the components of supervision were practiced in the public schools in the study area. The study established that generally instructional hours, regular in-service training and punctuality of teachers, head teachers and circuit supervisors were very effective in ensuring effective supervision. Another conclusion is that successful implementation of supervision is hampered by un-cooperative attitudes of both supervisors and supervisees, lack of funds and lack of follow ups on the part of supervisors. Again, a healthy supervisory relationship between supervisors and supervisees and provision of adequate funds could help address the challenges of supervision.

\section{Recommendations}

From the summary of the major findings of this study, the following recommendations are made:

1. Teachers and supervisors should be well informed about the activities entailed in supervision in order to demystify the outmoded perception of supervision so that each will know what is expected of them.

2. Regular in-service training should be organized by GES for supervisors and teachers to update their knowledge and skills so that they would be abreast, with the changing trends in school supervision.

3. There should be healthy and cooperative relationship between supervisors and supervisees to ensure that the benefits of supervision in public basic school are achieved.

4. The government through the Ministry of Education and the Ghana Education Service should provide supervisors with transportation allowance and other incentives in order to motivate them to give out their best so as to enhance quality teaching and learning in public basic schools.

\section{Suggestion for Further Study}

It is suggested that this study is replicated in all public basic schools in the Ghana so as to get a comprehensive picture of the nature of supervision, its effectiveness, and challenges and how to resolve these challenges to improve the quality of education delivery in the country.

\section{References}

Aluja-Fabregat, A., \& Blanch, A. (2004). Socialized personality, scholastic aptitudes, study habits, and academic achievement: Exploring the link. European Journal of Psychological Assessment, 20, 157-165. 
Vol.10, Issue 1, pp. 17-34, 2022

Online ISSN: 2054-636X (Online)

Print ISSN: 2054-6351(Print)

Ayse Bas, C. (2002). School-based supervision at private Turkish school: A model for improving teacher evaluation. Leadership and Policy in Schools, 1(2), 172190.

Baffour-Awuah, P. (2011). Supervision of instruction in public primary schools in Ghana: Teachers' and head teachers' perspectives. Retrieved from; http://www.researchrepository.murdoch.edu.au/8483/2/02Whole.pdf, on 14th January, 2013.

Bashir, I.\& Mattoo, N. H. (2012). A Study-on-Study Habits and Academic Performance Among Adolescents (14-19) years. International Journal of Social Science Tomorrow. 1(5), 1-5.

Blasé, J., \& Blasé, J. (1999). Principals' instructional leadership and teacher development: Teachers' perspectives. Educational Administration Quarterly, 35, 349- 378.

Cohen, L., Manion, L., \& Morrisson, K. (2011). Research Methods in Education, ( $^{\text {th }}$ ed.). London: Routledge.

Creswell, J. W. (2008). Research Design: Qualitative, Quantitative, and Mixed Methods Approaches (3rd ed.). Thousand Oaks, CA: Sage Publications, Inc.

Dampson, D. G., Kwaku, D., \& Mensah, D. (2010). Parental involvement in home work for children's academic success: a study in the cape coast municipality. Cape Town.

Dangara, U. Y. (2015). The Impact of Instructional Supervision on Academic Performance of Secondary School Students in Nasarawa State, Nigeria. Journal of Education and Practice, 6(10): 160-167.

Danso, A. P. (2009). Factors Affecting Instructional Supervision in Basic Schools: Case Study of Nsuta Circuit in the Techiman Municipality. (unpublished M.Ed thesis), University of Cape Coast.

Education Sector Performance Report, (2013). Republic of Ghana Ministry of Education: https://www.google.com.ghFinalEducationSectorReport.2013.pdf\&usg=AFQjCNEX bH2-26EOnArik2MC9TN8TGbKXA.

Etsey, Y. K. A., Amedahe, F. K., \& Edjah, K. (2004). Do private primary schools perform better than public schools in Ghana? Unpublished paper. Department of Education Foundations, University of Cape Coast, Cape Coast, Ghana.

Gall, M. D., Gall, J. P., \& Borg, W. R. (2003). Educational research: An introduction. Boston: Pearson Education.

Ghana Education Service (2021). Free senior high school statistics. Retrieve from ges.gv.gh.

Glanz, J., (1997). The Tao of Supervision, Taoist Insight into the Theory and Practice of Education Supervision. Journal of Curriculum and Supervision. 12(3):193211.

Kadingi, S. (2004). Policy Initiative for Change and Innovation in basic Education. Retrieved from: wwweducatejournal/indexphp/educate/article/download.org, on March 30, 2014.

Kochhar K. S. (2002). Secondary school administration. New Delhi, Sterling Publishers Pvt

Konchar, S. K. (2000). Secondary School Administration. New Delhi: Sterling Publishers Private Ltd. 
Vol.10, Issue 1, pp. 17-34, 2022

Online ISSN: 2054-636X (Online)

Print ISSN: 2054-6351(Print)

Kundu C. L., \&Tutoo D. N. (2000). Educational Psychology. New Delhi: Sterling Publishers PVT Ltd,

Kutsyuruba, B. (2003). Instructional Supervision: Perceptions of Canadian and Ukrainian Beginning High-School Teachers. (unpublished PhD Thesis). Saskatoon: University of Saskatchewan.

Mensah, A. (1995). Factors associated with high school learners' poor performance: A spotlight on mathematics and physical science. South Africa Journal of Education. 26(2):253-266.

Musaazi, J. C. S. (1985). The theory andpractice of educational administration. London: Macmillan Publishers.

Nakpodia, E. D. (2006). Educational Administration: A New Approach (2nd ed), Warri: Jonokase Publishers. Pp. 181-215.

National Open University of Nigeria (2006) Supervision of instruction in Education: Lagos: Press craft, production Company.

Oduro, G. (2008). Increased enrolment does not mean quality education [Electronic version]. Ghana News Agency. Retrieved from: http//: news.myjoyonline.com/education/200809/20151.asp, on May 22, 2015.

Okendu, J. N. (2012). The impact of school administrative structure and adequate supervision on the improvement of Instructional process. Academic Research Journal.Vol. 2(3).

Okwundu, N. S. (2012). Role of Supervision of Instruction as Quality Assurance Mechanism in Primary Schools in Abia Central Education Zone of Abia State. (M. ED Thesis, University of Nigeria).

Oyewole, B. K. \& Ehinola, H. (2014). Relevance of Instructional Supervision in the Achievement of Effective Learning in Nigerian Secondary Schools. Global Journal of Commerce \& Management Perspectives. Vol 3(3): 88-92.

Patton, M. (1990). Qualitative evaluation and research Methods. Newsbury Park: Sage Publications.

Rashid, A. (2001). Supervision practices as perceived by teachers and supervisors in Riyadh Schools. (unpublished doctoral thesis), Ohio University. Retrieved from: http://faculty ksu.edu.sa/dr.rashid/Documents/My20\%Dissertation.doc September 15.2006.

Saunders, M., Lewis, P., \&Thornhill, A. (2007). Research methods for business students (4th ed.) Harlow: Pearson Education.

Screens, I. Gerumi, S. \& Steen, L. (2011). Supervision and Clinical Psychology: Theory, practice and perspectives. Brunner-Routledge: New York NY 10001

Segun, O. (2004). Educational supervision: Perspective and practice in Nigeria. Ile Ife: University of Ile Ife.

Sergiovanni, T. J. \& Starratt, R. (2002). Supervision: A redefinition, ( $7^{\text {th }}$ ed.). New York: McGraw-Hill.

Sergiovanni, T. J., \& Starratt, R. (2002). Supervision: A redefinition (7th ed.). New York: McGraw-Hill.

Sidhu, K. G., \& Fook, Y. C. (2010). Formative supervision of teaching and learning: Issues and concerns for the school heads. European Journal of Scientific Research, 39(4): 589- 605. 
Sule, M. (2013). The influence of the principals' supervisory demonstration strategy on teacher's job performance in Nigeria secondary schools. IQSR journal of Humanities and Social science, 2(1): 39 - 44.

Sullivan, S., \& Glanz, J. (1999). Supervision that improves teaching strategies and techniques. Thousand Oaks, CA: Corwin Press Inc.

Sullivan, S., \& Glanz, J. (2000). Supervision that improves teaching: Strategies and techniques. Thousand Oaks, CA: Corwin Press Inc.

USAID (2006). Stakeholder Collaboration: An Imperative for Education Quality. Washington, DC: AED, EQUIP2 Program.

World Bank (2002). World Development Indicators. Retrieved from: http://www.publications.worldbank.org, on November 22, 2010. 